\title{
THE SHORTLIST
}

\author{
Time management.
}

\section{BY ADAM KUCHARSKI}

C 7 op work everyone. Seriously, this is outstanding." Hugo Vriers leafed through the stack of papers. "Two dogs and a monkey, extraordinary."

"Chimp," Professor Reed muttered.

Vriers squinted at the page. "Quite. And how is he doing, Janet?"

Dr Cranmer leant forward in her chair. "He's pretty sprightly, all things considered."

Vriers turned to Professor Garcia, who was busy jabbing his phone with an elderly finger. "Pablo, did everything stay within the limits this time?"

Garcia nodded. "All was smooth. No repeats of the second test."

"What happened in the second test?" Reed asked.

"Knocked out the power in half of London," Vriers said.

"Which half?"

"South."

Reed chuckled. "Ah well, these things happen."

"Tell that to the Mayor." Vriers pushed the papers to one side. "Now, there's a few things we need to discuss. I've had a chat with the board, and we've decided to draw up a shortlist of objectives."

Garcia shook his phone as if it were a sandy shoe. "Objectives?"

"Yes. We need a proper plan for this technology. It's all very well sending a beagle to the Renaissance or a chimp to the jazz age, but human time travel... well, the possibilities are endless. Literally."

"What's on your shortlist?" Reed asked.

Vriers flipped open a notebook. "Number one: 'Get rid of post tyrants.'” He paused. "Past. I think that should say 'past."

"Which ones?" asked Cranmer.

"We haven't decided yet. All of them perhaps? Top ten?" He tapped his pen against the pad. "Hitler seems like an obvious place to start."

Garcia frowned. "Time is a delicate tapestry. We should not naively pull at her threads."

Vriers looked at Cranmer, who shrugged, then turned back to Garcia. "I have a feeling you're not so keen, Pablo?"

Garcia sighed, shaking his head. "You talk of changing history as if it were a grocery list. We cannot just decide to-"

"Okay," Vriers said, "how about I just put Hitler for now? With $\rightarrow$ NATURE.COM

Follow Futures:

@NatureFutures

f go.nature.com/mtoodm maybe a little question mark in brackets. We can always add more later. Right, number two: mysteries. There's a few things we ought to get to the bottom of."

"Can we find out what happened to Kit Marlowe?" Cranmer asked.

Vriers' pen hovered over the page. "Shakespeare's friend? See, I'm not sure the board will go for that. How about Roswell, or JFK?"

"Or the Amber Room," Reed said.

"What's that?" Cranmer asked.

"Big room. Made of amber. Someone pinched it from the Russians in the '40s."

Cranmer raised her eyebrows. "Worth much?"

"Probably."

"Actually, is dosh on your list, Hugo?" she asked.

"Dosh?" Vriers said.

"With our machine, we could get the lottery numbers."

Vriers winced. "Isn't that a little...'

"A little?"

"Unethical? I imagine the committee would get annoyed."

"What committee?"

"I don't know. I just assumed you lot had a committee for that sort of thing."

Cranmer removed her glasses. "Even if we do, there isn't much in the kitty anymore."

Reed nodded. "And school fees don't pay themselves."

"I see," Vriers said, scribbling on his pad. "Right, how about this? 'Win lottery ... but only a bit."

"Need five year's boarding at least," Reed said.

"Very well." Vriers turned the page. "Next we have 'Inspiration'. The directors were hoping we could get some new ideas from somewhere. Or somewhen, rather. Any suggestions?"

"I'd love to meet Newton," Cranmer said. "That would certainly inspire me."

"And Monroe," Reed added.

"Can we try and focus on -"

"I think she was best in 1955," Reed said, leaning back in his chair. "The Seven Year Itch, what a -"

"The future!" Vriers groaned. "Please, concentrate on the future. What can we bring back? What technology do we need?"
"Do we not risk a paradox?" Garcia said. "I am concerned that - "

"It's fine," Vriers said. "Our logic team are on it."

"Logic team?" Reed asked.

"The laddies in the basement," Cranmer said, pointing downwards, "the ones with toy DeLoreans on their desks."

Reed laughed. "I thought they were someone's kids."

"It is not so simple," Garcia said. "No one can truly see how -"

"They know what they're doing," Vriers said. "Trust me, we're fine on the paradox front."

"As long as nobody gets someone pregnant," Cranmer said.

"What?"

"You know, like in The Terminator. Time babies."

"Look, nobody is having any, um, time..."

"Babies."

"... time babies. Now, let's focus on business. There are nine more objectives to get through." Vriers glanced at his phone, sat atop one of the piles of papers. "It's almost three oclock, and I've got a meeting at four. So let's get on with it."

As he picked up his pen, the phone started to ring. He answered it and a draught sent the documents billowing across the room.

"Are you serious?" Vriers asked, surrounded by the dancing sheets. He waved them away, the colour draining from his face. "When did this happen? Who left it turned on? Okay, I'll be right down."

"What's the problem?" Cranmer said.

Vriers stood up. "The chimp's stolen the machine."

"Sorry, what?"

"The chimp. He's vanished with the machine."

The room fell silent.

"Come on," Vriers said, slamming his palms against the table. "Don't just sit there! We need to get it back! Think, what are we going to do?"

Garcia smiled. "Put it on your list?"

Adam Kucharski is based in London, where he researches the cocktail of influences behind disease outbreaks. 